\title{
Maternal depression: Associations between behavioral problems in school-aged children, organization patterns, adversities, and family environment resources
}

\author{
Depressão materna: associações entre problemas \\ comportamentais de escolares e padrões \\ de organização familiar
}

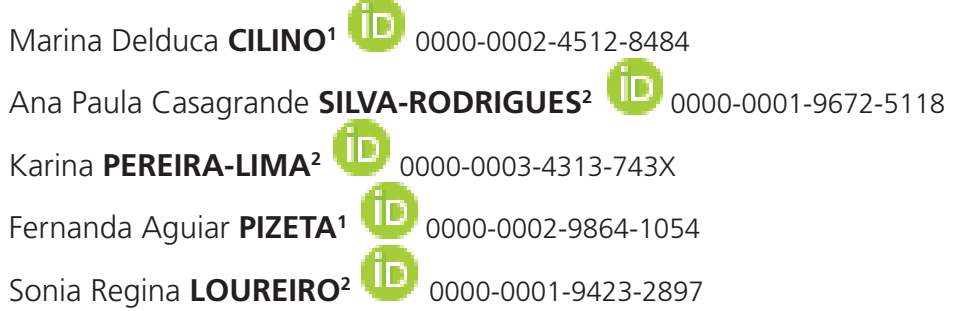

\begin{abstract}
The objective of this study was to verify possible associations between family organization patterns, adversities, family environment resources, and behavioral problems "in children of mothers with recurrent depression" (Group 1) compared with "children of mothers without psychiatric disorders" (Group 2). A total of 100 mother-child dyads were divided into two equal groups and were evaluated individually using the following instruments: General questionnaire; Structured

1 Universidade de São Paulo, Faculdade de Filosofia, Ciências e Letras, Departamento de Psicologia, Programa de Pós-Graduação em Psicologia. R. Tenente Catão Roxo, 2650, 14051-140, Ribeirão Preto, SP, Brasil. Correspondência para/Correspondence to: M.D. CILINO. E-mail: <marinacilino@yahoo.com.br>.

2 Universidade de São Paulo, Faculdade de Medicina, Departamento de Neurociências e Ciências do Comportamento, Programa de Pós-Graduação em Saúde Mental. Ribeirão Preto, SP, Brasil.

Support: Coordenação de Aperfeiçoamento de Pessoal de Nivel Superior; Fundação de Amparo à Pesquisa do Estado de São Paulo (Process no 2014/06972-7); Conselho Nacional de Desenvolvimento Científico e Tecnológico (Process n 307394/2014-0).

Article based on the doctoral dissertation of M.D. CILINO, entitled "Padrões organizacionais familiares de crianças que convivem com a depressão materna". Universidade de São Paulo, 2017.

$\boldsymbol{v} \mathbf{v} \boldsymbol{v}$

Como citar este artigo/How to cite this article

Cilino, M. D., Silva-Rodrigues, A. P. C., Pereira-Lima, K., Pizeta, F. A., \& Loureiro, S. R. (2018). Maternal depression: Associations between behavioral problems in school-aged children, organization patterns, adversities, and family environment resources. Estudos de Psicologia (Campinas), 35(4), 399-410. http://dx.doi.org/10.1590/1982-02752018000400007
\end{abstract}


Clinical Interview for Diagnostic and Statistical Manual of Mental Disorders; Strengths and Difficulties Questionnaire; Escala de Eventos Adversos; Escala de Adversidade Crônica; Inventário de Recursos do Ambiente Familiar; Raven, and an interview about family patterns. When compared to Group 2, Group 1 showed significantly more behavioral problems, adverse events, and chronic adversities and fewer family resources and family organization patterns. Negative and moderate associations were observed between behavioral problems and positive family organization patterns, evidencing the importance of mental health actions aimed at improving these patterns.

Keywords: Child; Child behavior; Depression; Mothers; Risk factors.

\section{Resumo}

Objetivou-se verificar as possíveis associações entre padrões de organização familiar, adversidades e recursos do ambiente familiar e problemas de comportamento de "crianças que convivem com mães com depressão recorrente" (Grupo 1), em comparação às que "convivem com mães sem transtornos psiquiátricos" (Grupo 2). Avaliaram-se individualmente cem díades mãe-criança, distribuídas em dois grupos do mesmo tamanho amostral, por meio dos instrumentos: Questionário Geral; Entrevista Clínica Estruturada para Manual Diagnóstico e Estatístico de Transtornos Mentais; Questionário de Capacidades e Dificuldades; Escala de Eventos Adversos; Escala de Adversidades Crônicas; Inventário de Recursos do Ambiente Familiar, Raven e Entrevista sobre padrões de organização familiar. Em comparação ao Grupo 2, o Grupo 1 apresentou significativamente mais problemas comportamentais, bem como eventos adversos, adversidades crônicas e menos recursos do ambiente familiar e padrões de organização familiar. Foram detectadas correlações negativas e moderadas entre problemas comportamentais e padrões positivos de organização familiar, evidenciando a relevância de ações em saúde mental que favoreçam o desenvolvimento desses padrões.

Palavras-chave: Criança; Comportamento infantil; Depressão; Mães; Fatores de risco.

Depression is a condition that is reportedly more prevalent in women than in men (Almeida \& Faro, 2016). It affects daily care and the daily life of women/mothers due to its common characteristics and symptoms (American Psychological Association [APA], 2014), which may impair the ability to parent and influence family environment and organization.

According to Psychogiou and Parry (2014), parents' depression has a negative effect on parentchild interactions, affecting daily care and the developmental outcomes of children exposed to this maternal psychopathology (Cid \& Matsukura, 2014; Jacobs, Talati, Wickramaratne, \& Warner, 2015). According to the meta-analysis carried out by Goodman et al. (2011), maternal depression was associated with higher levels of internalizing and externalizing behavioral problems, general psychopathology, and negative affect in children. Other recent studies have shown that maternal depression was associated with behavioral problems (Shaw, Stinick, Reuben, Dishion, \& Wilson, 2016) and depressive symptoms in children exposed to recurrent maternal depression (Mikkonen, Moustgaard, Remes, \& Martikainen, 2016).

Children of clinically depressed mothers 400 are exposed to other adversities in the family environment (Barker, Copeland, Maughan, Jaffee, \& Uher, 2012), such as low level of maternal education and single parenting (Goodman et al., 2011; Talati et al., 2007), low socio-economic status (BouvetteTurcot et al., 2017), and little health care and poor eating habits (Brecailo \& Saldan, 2013). Moreover, as reported in the review conducted by Pizeta, Silva, Cartafina, and Loureiro (2013), parenting style, organization, and family interactions associated with maternal depression adversities also influence child mental health.

Accordingly, in addition to the risks for adverse child development, it is necessary to consider the mechanisms that can protect or neutralize adverse impacts on children and families (Linhares, 2016). Walsh (2016) argued that in order to deal with adverse conditions, families count on protective resources that enable adaptation, such as family organization patterns.

Many studies have shown that family system organization can be characterized as a protective resource for children development in terms of assigning responsibilities, establishing rules (Cid, 2015) and daily routine consisting of well-defined schedule (Ferriolli, Marturano, \& Puntel, 2007; 
Marturano \& Elias, 2016), parental involvement in children activities (Dorsch, Smith, \& McDonough, 2015; Fosco, Stormshak, Dishion, \& Winter, 2012), and flexibility to change routines and rules (Gomes \& Pereira, 2014; Walsh, 2016).

When emphasizing the negative effect of parents' depression on their interactions with their children, Psychogiou and Parry (2014) pointed out the need to improve the understanding of the mechanisms underpinning impaired parenting and daily care. The authors highlighted the need for new studies, involving the same population group, addressing the risk and protective factors of families facing maternal depression.

The present study contributes to bridge these research gaps and aims to verify possible associations between family organization patterns, adversities, family environment resources, and behavioral problems in children of mothers with recurrent depression by comparing them to children of mothers without psychiatric disorders.

\section{Method}

A cross-sectional correlation research design was used for this study. It was approved by the Research Ethics Committee of the Hospital das Clínicas de Ribeirão Preto, 6395/2011, according to the principles laid down in the Declaration of Helsinki.

\section{Participants}

The convenience sample consisted of 100 mother-child dyads divided into two Groups: G1 - 50 mother-child dyads composed of mothers diagnosed with recurrent depressive disorder and who had had at least one moderate or severe episode in the two years prior to data collection and no episodes in the last six months and who were receiving outpatient mental health clinic follow-up; G2 - 50 mother-child dyads composed of mothers without psychiatric disorders, who were receiving outpatient Family Health Unit (FHU) follow-up.
Mothers aged between 25-45 years with children aged 7-12 years were selected. They were identified through health facilities in the municipal and state healthcare network of a medium-sized city located in an inland city in São Paulo state, Brazil. The children were identified through their mothers.

Inclusion criteria were as follows: diagnosis of recurrent depression for $\mathrm{G} 1$ mothers, based on depressive disorder symptoms, according to the criteria of the International Statistical Classification of Diseases and Related Health Problems (ICD-10) (World Health Organization, 2017); absence of mental disorders for G2 mothers, which were systematically evaluated. The exclusion criteria for G1 were mothers who had a single major depressive episode, those who had mild episodes, and those with comorbidities of psychiatric disorders. For both groups, mothers who reported having severe chronic diseases were excluded.

Children of both sexes who scored higher or equal to the low average percentile in the Raven's Colored Progressive Matrices Test and who lived with their biological mothers were included (only one child per family). Orphans, adopted children, and children with mental retardation and apparent sensory disabilities were excluded to enable control of other variables that could affect their behavior.

To form G1, 7,721 medical records including four years of recorded information were reviewed. A total of 268 mothers diagnosed with recurrent depression with moderate, severe, or remission episodes and who had children between ages of 7 and 12 years were identified. Of the 268 identified mothers, 218 dyads were excluded due to the following reasons: mothers had depressive symptoms at the time data were collected (92), mothers were not located (61), mothers refused to participate (34), mothers had other psychiatric disorders (27), and children had sensory or mental disabilities (4). G2 was composed of 153 women that were identified through a list provided by the FHU and 103 were excluded due to the following reasons: mothers refused to participate (39), mothers had depressive symptoms or psychiatric disorders (34), mothers were not located (27), and children had sensory disabilities (3). 


\section{Instruments}

Designed to assess the socio-demographic characteristics of the participants and their families. The socio-economic characteristics were assessed using the Critério de Classificação Econômica Brasil (CCEB, Brazilian Economic Classification Criteria), established by the Associação Brasileira de Empresas de Pesquisas (ABEP, Brazilian Association of Research Enterprises).

\section{Structured Clinical Interview for DSM-IV (SCID)}

Used to evaluate the diagnostic of presence or absence of psychiatric disorders. This semistructured interview is considered as the gold standard for psychiatric diagnosis. The version used was translated and adapted for the Brazilian population by Del-Ben et al. (2001), who used Kappa Coefficient to test its reliability and found a high value of weighted Kappa ( $K w=0.83)$. The General Review, SCID I (modules A, B, C, D, E, and F) and SCID II were used for $G 1$ aiming at applying the inclusion criteria established for the mothers. The SCID-NP version of the interview was conducted with G2 mothers for the exclusion of psychiatric disorders. It should be noted that the Diagnostic and Statistical Manual of Mental Disorders - DSM-5 (APA, 2014), currently in its fifth edition, contains the same diagnostic criteria for persistent depressive disorders described in the previous version, which were used for the development of SCID.

\section{Strengths and Difficulties Questionnaire}

Used to measure children's behavioral problems. It is free to download (mww.sdqinfo.com) and was developed by Goodman (1997) to screen for behavioral problems in Children and adolescents (4-16 year-olds) in the past six months. It was translated and adapted to the Brazilian population by Fleitlich, Cortázar, and Goodman (2000). It has three different versions (for parents, teachers, and youngsters aged 11 and older); in the present study the version for parents was used. It consists of 25 items divided into four scales that probe difficulties (Emotional Symptoms, Conduct Problems, Hyperactivity-inattention, and Peer Problems and one scale that probes strengths (Prosocial Behavior); these 5 scales have scale five items each. The total difficulties score is obtained by the sum of the scores on the four scales that probe difficulties, ranging from 0-40. The classification as "with behavioral problem" and "without behavioral problems" was based on the cut-off score indicating a problem (total score greater than 16), as proposed by Goodman (1997) for the total difficulties score. The reliability and validity of the instrument in Brazil were evaluated by Woerner et al. (2004), who found good psychometric properties. The test-retest reliability method and Cronbach's alpha were used to assess reliability, and no statistically significant differences were found between them. The questionnaire was administered at an average interval of approximately 20 days ( $p=0.148$ ) with 0.79 of correlation between the scores and intraclass correlation of $0.77(p<0.001)$. To assess validity, the authors compared the Strengths and Difficulties Questionnaire to the Rutter questionnaires and the Child Behavior Checklist (CBCL) (correlations of 0.90 and 0.87 , respectively), and also with the diagnostic instrument Development and Well-Being Assessment for Children and Adolescents (DAWBA) $\left(\chi^{2}=13.1, p<0.001\right)$.

\section{Adverse Event Scale and Chronic Adversity Scale}

Used to identify adverse events and chronic stressors, respectively, in children and families. These scales were proposed by Marturano (1999) and are aimed at detecting adverse events (occasional occurrence in the past 12 months or before) and chronic adversities (since the birth of the child with duration or repeated occurrence for a year or longer) that may have occurred in the child's life. The Escala de Eventos Adversos (EEA, Adverse Event Scale) consists of 36 items, which can be classified into three domains: (a) school life, (b) family life, and (c) personal life. The test-retest reliability method was used to assess reliability, showing stability 
indexes of $100 \%, 97 \%$, and $94 \%$, respectively, between the scale scores obtained in the two times they were applied with a 20-day interval (Santos, 1999). The Escala de Adversidade Crônica (EAC, Chronic Adversity Scale) contains 18 items that encompass chronic adversities related to: (a) child and parents' health (b) parents' temperament, and (c) possible family and marital conflicts.

\section{Family Environment Resource Inventory}

Used to identify resources and possible positive organization patterns in the family environment. It was developed by Marturano (2006) to identify family resources that can be associated with school performance. It has 10 topics related to resources: (a) children's activities when they are not in school; (b) leisure time shared or promoted by the parents; (c) children's regular scheduled activities; (d) parent- child shared activities at home; (e) availability of toys and other materials that promote child development; (f) availability of magazines and newspapers; (g) availability of books; (h) parents' supervision of children's academic achievement; (i) regular daily schedule; and (j) promotion of family time. In a sample of 100 children having school problems, the psychometric indices (92\%-100\%) showed good stability in terms of total score, using the test-retest method (Santos, 1999).

\section{Semi-structured interview}

Used to identify indicators of positive family organization patterns for the identification of protective mechanisms of child development. It was developed by Pizeta (2014) to evaluate indicators related to the key processes in family resilience, proposed by Walsh $(2006,2016)$. In the present study, only the interview topics concerning family organization patterns were considered. These topics' responses were categorized as follows: (1) Flexibility and Reorganization, (2) Routine Stability and Time Management, (3) Parental Involvement in Children's Daily Routine, and (4) Psychosocial Support and Socio-economic Resources. The reliability of the instrument was assessed using Cronbach's alpha (0.814).

\section{Raven's Colored Progressive Matrices Test: Special Scale}

Performance on this test (at $\geq 25^{\text {th }}$ percentile) was one of the inclusion criteria for selection of children in this study. It is an instrument used to evaluate children's level of intellectual functioning, and it was standardized for a representative sample of Brazilian children by Angelini, Alves, Custódio, Duarte, \& Duarte, 1999). Construct validity of the test was verified based on the progressive increase in the test results, according to the chronological age of the children evaluated and the internal consistency of the test, which was satisfactory for most items; item-total correlation ranged from 0.30 to 0.80 . As for the test precision, the correlation coefficient between the items (split-halves method) for the total sample was 0.92 (Angelini et al., 1999).

\section{Procedures}

After signing the Informed Consent form, the mothers were evaluated by trained psychologists. Data were collected through face-to-face interactions in two or three individual sessions that lasted 60-120 minutes (average of 85 minutes). In the first session, the General Questionnaire, SCID, SDQ, EEA, EAC, and Family Environment Resource Inventory were administered, and in the second session, the Semi-structured Interview was conducted and audio-recorded. When necessary, a third session was held to conclude this interview.

The children were evaluated by trained psychology students in a single session that lasted 10-30 minutes (average of 15 minutes) using the Raven's Colored Progressive Matrices Test Special Scale.

\section{Data Treatment}

The data obtained using the SCID and Raven's Matrices test were used only to select 
participants to be included in the groups. The SDQ, EEA, EAC, and RAF data were coded according to the technical standards of each instrument. The information obtained by the General Questionnaire was codified to define the children, mothers, and families' characteristics.

The responses to the Semi-structured Interview selected topics were transcribed fully and literally. These data were categorized and coded following the method proposed by BiasoliAlves (1998) to interpret the items based on the theoretical framework of developmental psychopathology to identify indicators of positive family organization patterns. These indicators were coded using four previously defined categories with scores ranging from 0 to 42.0 The higher the score, the higher the number of family protective factors. The coding categories were defined by two researchers independently for $30.00 \%$ of the transcribed interviews, accounting for $87.27 \%$ of agreement.

Data were submitted to statistical analysis using the Statistical Package for Social Sciences (SPSS - Chicago, IL, USA), version 17 for Windows. Initially, the Kolmogorov-Smirnov and Shapiro-Wilk tests of normality were performed. Descriptive statistics was then used. The comparisons between the groups were made using the Pearson's chisquare test, the Fisher's exact test (categorical variables), and the Student's t-test (continuous variables). Univariate logistic regression was carried out to verify the possible influence of the sociodemographic variables that distinguished the groups in terms of the behavioral indicators in the children evaluated. Pearson's correlation was used to identify possible correlations between the following variables: socio-demographic characteristics of the mother-child dyads, behavioral indicators in the children, adverse events, chronic adversities, family environment resources, and family organization patterns. Spearman correlation was used to identify possible correlations between maternal depression and other variables. The classification system proposed by Maroco (2014) was used to classify the strength of the correlations, as follows: weak (0-0.25), moderate (0.25-0.50), strong (0.50-0.70), or very strong (>0.70). The significance level of $5 \%$ $(p \leq 0.05)$ was adopted for all tests.

\section{Results}

With regard to the socio-demographic characteristics, the mean age of the children was 9.9 years $(S D=1.69)$, all of them attended elementary and middle school, and the majority $(61 \%)$ was enrolled in early grades (1st-5th grades). The chi-square tests showed that the children were evenly distributed between the groups in terms of the number of children under 10 years of age: males (G1 $=48 \%, G 2=52 \%, p=0.689)$ and females ( $\mathrm{G} 1=48 \%, \mathrm{G} 2=42 \%, p=0.841)$. No statistically significant differences were observed between these variables and between number of children enrolled in the early grades of elementary school (G1 $=48 \%, G 2=52 \% ; p=0.682)$. Mothers' mean age was 36.2 years $(S D=5.02)$; most of them reported having more than eight years of education (56\%), having a partner (64\%); having a paid job (63\%), and having 1-3 children (87\%). Most families (58\%) were classified as belonging to socio-economic classes $A$ and $B$.

As for the socio-demographic variables, the chi-square tests showed no statistically significant differences in terms of having paid jobs ( $G 1=72 \%$, $\mathrm{G} 2=54 \%, p=0.062$ ), which shows an even distribution between the groups concerning this variable. However, a significant statistical difference was found in the comparisons between the groups in terms of level of education, number of children, marital status of the mothers, and the socio-economic status of the families. $\mathrm{G} 1$ had more mothers with less than 8 years of education (G1 $=62 \%, G 2=$ $26 \%, p=0.001)$, with more than three children (G1 $=20 \%, G 2=6 \%, p=0.037)$, who did not live with a partner $(\mathrm{G} 1=66 \%, \mathrm{G} 2=6 \%, p<$ $0.001)$, and families with fewer socio-economic resources, classes $A$ and $B(G 1=38 \%, G 2=78 \%$, $p<0.001)$. Logistic regression showed that the mother's level of education (Odds Ratio $-O R=$ $2.031, p=0.376)$, number of children $(O R=1.909$, $p=0.395)$, marital status $(O R=1.368 ; p=0.766)$, and the socio-economic status of the families $(O R=2.031, p=0.376)$ did not influence, with 
statistical significance, the behavioral indicators of G1 children.

With regard to the children behavioral profile, Table 1 shows the comparisons between the groups in relation to the Total Difficulties score and the scores on the SDQ specific Scales, considering the mean and standard deviation.

Significant statistical differences were found between the groups. G1 had higher mean scores for the children behavior, which was assessed in relation to the Total Difficulties score and the subscales Emotional Symptoms, Hyperactivity-inattention, and Peer Problems, and also in relation to the Pro-
Social Behavior Scale, related to pro-social resource; $\mathrm{G} 1$ mean value was lower than that of $\mathrm{G} 2$, with a significant statistical difference.

Considering the cut-points for SDQ scores, it was verified that most children $(70 \%)$ did not have behavioral problems, and they were classified as "without behavioral problem" in terms of the SDQ Total Difficulties Score. The majority of the children included in this category belonged to $G 2$. It was also found that $\mathrm{G} 1$ children of mother with depression were three times more likely to have behavioral problems $(O R=3.299, p=0.016$, $95 \% \mathrm{Cl}=1.322 ; 8.231)$.

Table 1

Comparisons between groups (G1 and G2) regarding children's behavior (SDQ - Total Difficulties Scores and Scale Scores) $(n=100)$

\begin{tabular}{|c|c|c|c|c|c|c|}
\hline \multirow{2}{*}{ SDQ scores } & \multicolumn{2}{|c|}{$\mathrm{G} 1(\mathrm{n}=50)$} & \multicolumn{2}{|c|}{$\mathrm{G} 2(\mathrm{n}=50)$} & \multirow{2}{*}{$t$} & \multirow{2}{*}{$p$-value } \\
\hline & Mean & SD & Mean & SD & & \\
\hline Total Difficulties & 15.12 & 6.92 & 9.08 & 6.64 & 4.45 & $<0.001$ \\
\hline Emotional Symptoms & 5.20 & 2.60 & 2.80 & 2.30 & 4.88 & $<0.001$ \\
\hline Conduct Problems & 2.54 & 2.27 & 1.82 & 1.90 & 1.72 & 0.09 \\
\hline Hyperactivity-Inattention & 4.74 & 3.20 & 3.22 & 3.16 & 2.39 & 0.02 \\
\hline Peer Problems & 2.62 & 1.82 & 1.24 & 1.57 & 4.06 & $<0.001$ \\
\hline Pro-Social Behavior & 8.50 & 1.61 & 9.10 & 1.45 & -1.96 & 0.05 \\
\hline
\end{tabular}

Note: ${ }^{*} p$-value for Student's $t$-test $/ p \leq 0.05$.

SDQ: Strengths and Difficulties Questionnaire; G1: Children of mothers with a history of recurrent depression; G2: Children of mothers without a history of any psychiatric disorder; SD: Standard Deviation.

Table 2

Comparisons between groups (G1 and G2) regarding stressors (EEA), chronic adversity (EAC), family environment resources (RAF), and family organization patterns $(n=100)$

\begin{tabular}{|c|c|c|c|c|c|c|}
\hline \multirow{2}{*}{ Variables } & \multicolumn{2}{|c|}{$\mathrm{G} 1(\mathrm{n}=50)$} & \multicolumn{2}{|c|}{$\mathrm{G} 2(\mathrm{n}=50)$} & \multirow{2}{*}{$t$} & \multirow{2}{*}{$p$-value* } \\
\hline & Mean & SD & Mean & SD & & \\
\hline EEA & 14.08 & 5.12 & 8.38 & 4.08 & -6.16 & $<0.001$ \\
\hline EAC & 3.92 & 1.82 & 2.22 & 1.61 & -4.96 & $<0.001$ \\
\hline RAF & 57.76 & 10.49 & 62.12 & 8.66 & 2.26 & 0.03 \\
\hline Total Organization Patterns & 17.98 & 4.58 & 24.60 & 4.97 & 6.92 & $<0.001$ \\
\hline Flexibility and Reorganization & 3.54 & 1.61 & 5.78 & 1.54 & 7.08 & $<0.001$ \\
\hline Routine Stability and Time Management & 5.14 & 2.03 & 7.70 & 2.14 & 6.14 & $<0.001$ \\
\hline Involvement in Children's Daily Routine & 4.48 & 2.74 & 5.22 & 2.92 & 1.30 & 0.20 \\
\hline Psychosocial Support and Socioeconomic Resources & 4.82 & 1.28 & 5.90 & 1.58 & 3.74 & $<0.001$ \\
\hline
\end{tabular}

Note: ${ }^{*} p$-value for Student's $t$-test $/ p \leq 0.05$.

G1: Children of mothers with a history of recurrent depression; G2: Children of mothers without a history of any psychiatric disorder; SD: Standard Deviation; EEA: Escala de Eventos Adversos (Adverse Event Scale); EAC: Escala de Adversidade Crônica (Chronic Adversity Scale); RAF: Inventário de Recursos do Ambiente Familiar (Family Environment Resources Inventory). 
As for the family profile, Table 2 shows the comparisons between the groups in terms of adverse events (EEA), chronic adversity (EAC), family environment resources (RAF), and Positive Family Organization Patterns.

There were statistically significant differences between $\mathrm{G} 1$ and $\mathrm{G} 2$ in the two scales related to risk factors. The $\mathrm{G} 1$ mean values were higher than those of $\mathrm{G} 2$ for both the presence of adverse events and chronic adversities. Differences with statistical significance were also identified between the groups in relation to protective factors, and the $\mathrm{G} 1$ mean values were lower than those of $\mathrm{G} 2$ for the presence of family environment resources, total positive organization patterns, and the following categories: Flexibility and Reorganization; Routine Stability and Time Management; and Psychosocial Support and Socioeconomic Resources.

Table 3 shows the correlations between the following variables: maternal depression, behavioral indicators (SDQ), total adverse events (EEA), total chronic adversity (EAC), total family environment resources (RAF), and Positive Family Organization Patterns (Interview).

There were 36 significant correlations between the variables in the present study. The strength of these correlations was classified as strong (3), moderate (23), and weak (6).

The variables related to family context were significantly correlated with the children's behavioral problem scores, especially the large effect size of the relationship between maternal depression and emotional problems $\left(r^{2} s=0.217\right)$, between adverse events and chronic adversity $\left(r^{2} s=0.149\right)$; between total problems and adverse events and chronic adversities ( $r^{2} s=0.149$ for both), and between emotional problems and adverse events and chronic adversities ( $r^{2} s=0.144 ; r^{2} s=0.131$, respectively). With regard to the family environment resources, there were negative correlations with the scores of children's behavioral problems, and the relationship between RAF and emotional symptoms had the largest effect size $\left(r^{2} s=0.071\right)$. There were also positive correlations between maternal depression with adverse events $\left(r^{2} s=0.286\right)$ and chronic adversities $\left(r^{2} s=0.176\right)$, and negative correlations with family environment resources $\left(r^{2} s=0.360\right)$.

\section{Discussion}

The family context of children of depressed mothers was characterized by a socio-demographic

Table 3

Correlations between Maternal Depression (MD), Positive Family Organization Patterns (PFOP), Adverse Events (EEA), Chronic Adversity (EAC), Family Environment Resources (RAF), and Behavioral Indicators (SDQ)

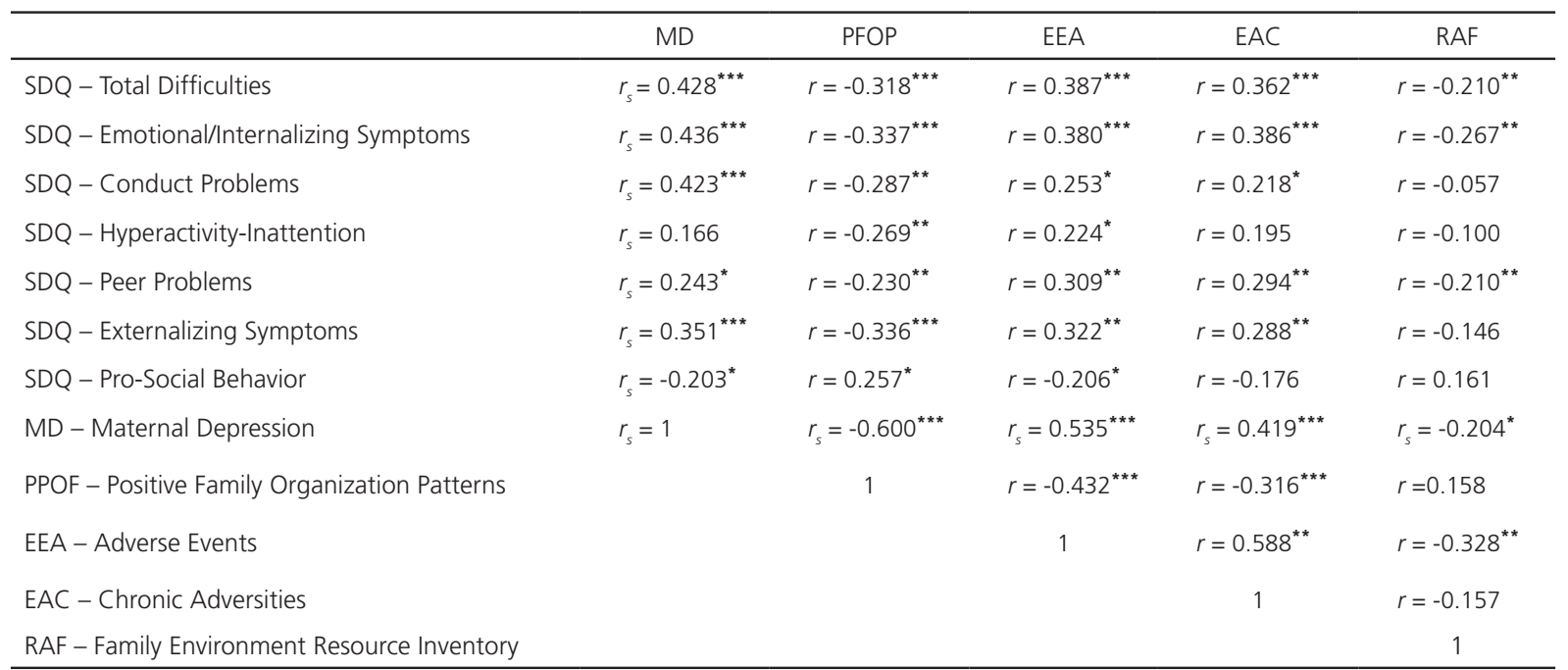

Note: ${ }^{*} p<0.05 ;{ }^{* *} p<0.01 ;{ }^{* * *} p<0.001$

406

$r_{s}$ : Spearman's correlation coefficient; $r$ : Pearson's correlation coefficient. 
factors considered conducive for child maladaptation, as previously reported in other studies (Barker et al., 2012). The association of such psychopathology with low maternal education (Talati et al., 2007), lower socio-economic status of the families (Bouvette-Turcot et al., 2017), and single-parent family status (Goodman et al., 2011) indicates social vulnerability of depressed mothers. Despite characterizing a context with multiple adversities, this socio-demographic profile does not include variables that can alone explain the presence of behavioral problems in children, as shown by the logistic regressions carried out. This indicates a need to expand the knowledge about the context of families with recurrent depression.

This finding is worthy of note due to the greater number of children exposed to recurrent maternal depression and who had behavioral problems, in agreement with the results of other studies (Goodman et al., 2011; Cid \& Matsukura, 2014, Shaw et al., 2016, especially regarding Emotional and Internalizing Symptoms (Jacobs et al., 2015; Mikkonen et al., 2016). Therefore, in the present sample, the exposure to recurrent maternal depression can be considered a risk factor related to the development of school-aged children who are in social vulnerability situation with more chronic adversity and adverse events. It is thus clear that children of mothers with depression are exposed to cumulative risks that may increase the impact of depression on child outcomes (Barker et al., 2012).

The results obtained also suggest that the effect of depression on the family extends far beyond, impacting home organization, in terms of the capacity for flexible reorganization in the face of adversity. These factors were evaluated in the present study based on families' routine, time management skills, and maternal perception of psychosocial support and socio-economic resources. Due to their peculiarities, the symptoms of recurrent depressive disorder make it difficult to establish a routine and get on with day-today activities, and to organize activities and the time devoted to their children. These results corroborate with data showing that children of depressed mothers are exposed to the worst health care, eating habits, and development promotion conditions (Brecailo \& Saldan, 2013).

The total of Organizational Patterns was negatively associated with the presence of more adverse events and chronic adversities, suggesting that the families' ability to adapt in the face of these events is lower than that when they are exposed to a greater number of stressors and chronically destabilizing situations. Therefore, in the presence of recurrent maternal depression, there is a possible relationship between multiple and cumulative adversities and families' inability to establish regular routines, reorganize, and adapt flexibly due to their family situation.

Another point to highlight is the possible difficulties of parents in getting involved with daily activities of their children. Despite the maternal perception of father involvement as a protective resource for child development (Dorsch et al., 2015; Fosco et al., 2012), paternal involvement was less frequent in $\mathrm{G} 1$ than in $\mathrm{G} 2$.

Psychosocial support and socio-economic resources were reported as lower by G1 mothers than by $\mathrm{G} 2$ mothers. This may be due to the fact that G1 mothers had lower level of education and lower income, and there was less involvement of their partners in caring for children. This hindered perception of the support received and the resources available can be considered as a source of risk for family organization, and it accentuate other difficulties resulting from recurrent maternal depression.

The association between children's behavioral problems and fewer family organization resources suggests that the difficulties with reorganization in the face of adversities, routine stability, and time management observed in $\mathrm{G} 1$ families may be leading to behavioral problems in children, who are already exposed to cumulative stressors. These findings corroborate those of Ferriolli et al. (2007), regarding the impacts on children behavior living with lack of routine and well-defined schedule, and those of Gomes and Pereira (2014), regarding low family flexibility as an unfavorable condition affecting all family members and offspring. 
The analysis of these associations clearly shows the importance of identifying family organization conditions that may be possible protective factors of children development. This is due to the importance of actions that promote family protective resources, such as those proposed by Linhares (2016) and Walsh (2016), corroborating the empirical data reported by Cid (2015) and Marturano and Elias (2016).

However, the present study has some limitations. The first one is related to the crosssectional and correlational design, which did not allow the determination of the predictive value of the variables for the behavior of the children of depressed mothers and the analysis of this impact over time. In addition, it was not possible to carry out specific analyses in terms of gender differences due to the small size of the sample. Another limitation is that the mothers were the only informants regarding their children's behavior, although G1 mothers' depressive symptoms went into remission at the time data were collected. On the other hand, some positive aspects of the present study include the methodological approach adopted in terms of addressing, in the same sample, the association of maternal depression with other contextual risk and protective factors, focusing on their effect on children's behavior. This allowed us to broaden our understanding of this issue and to highlight the influence of family organization patterns on the behavior of school-aged children.

Considering that positive family organization patterns can reduce childhood behavioral problems and due to the fact that in the context of maternal depression these patterns are less frequent, it is suggested that maternal and child mental health prevention and treatment programs address the improvement of positive family organization patterns to include protective resources for mothers and for child development.

\section{Contributors}

M.D. CILINO contribututed to the conception and design of this study, data analysis and interpretation, discussion of results, and manuscript revision and approval of the final version. A.P.C. SILVA-RODRIGUES contribututed to data collection and interpretation, discussion of results, and manuscript, revision, and approval of the final version. K. PEREIRA-LIMA contribututed to data analysis and interpretation and approval of the final version. F.A. PIZETA contribututed to the conception and design of this study, data analysis and interpretation, discussion of results, and manuscript revision and approval of the final version. S.R. LOUREIRO contribututed to the conception and design of this study, data analysis and interpretation, discussion of results, and manuscript revision and approval of the final version.

\section{References}

Almeida, L. G. R., \& Faro, A. (2016). Levantamento e principais achados de estudos nacionais sobre a depressão. Revista Interdisciplinar de Pesquisa e Inovação, 2(1),1-16.

American Psychiatric Association. (2014). Manual diagnóstico e estatístico de transtorno: DSM-5 (5a ed.). Porto Alegre: Artmed Editora.

Angelini, A. L., Alves, I. C., Custódio, E. M., Duarte, W. F., \& Duarte, J. L. (1999). Manual das matrizes progressivas coloridas de Raven: escala especial. São Paulo: Centro Editor de Testes e Pesquisas em Psicologia.

Barker, E. D., Copeland, W., Maughan, B., Jaffee, S. R., \& Uher, R. (2012). Relative impact of maternal depression and associated risk factors on offspring psychopathology. The British Journal of Psychiatry, 200(2), 124-129. http://dx.doi.org/10.1192/bjp.bp. 111.092346

Biasoli-Alves, Z. M. M. (1998). A pesquisa em psicologia: análise de métodos e estratégias na construção de um conhecimento que se pretende científico. In G. Romanelli \& Z. M. M. Biasoli-Alves (Orgs.), Diálogos metodológicos sobre prática de pesquisa (pp.135-157). Ribeirão Preto: Legis Summa.

Bouvette-Turcot, A., Unternaehrer, E., Gaudreau, H., Lydon, J. E., Steiner, M., \& Meaney, M. J. (2017). The joint contribution of maternal history of early adversity and adulthood depression to socioeconomic status and potential relevance for offspring development. Journal of Affective Disorders, 207, 26-31. http:// dx.doi.org/10.1016/j.jad.2016.08.012

Brecailo, M. K., \& Saldan, P. C. (2013). Relação entre depressão materna e os cuidados em saúde à criança: revisão sistemática. UNOPAR Científica Ciências Biológicas e da Saúde, 15(Esp.), 423-429.

Cid, M. F. B. (2015). Cotidiano familiar: refletindo sobre a saúde mental infantil e a prática de atividades familiares. Revista de Terapia Ocupacional da Univer- 
sidade de São Paulo, 26(3), 428-438. http://dx.doi. org/10.11606/issn.2238-6149.v26i3p428-438

Cid, M. F. B., \& Matsukura, T. S. (2014). Problemas de saúde mental em escolares e seus responsáveis: um estudo de prevalência. Revista de Terapia Ocupacional da Universidade de São Paulo, 25(1),1-10. http:// dx.doi.org/10.11606/issn.2238-6149.v25i1p1-10

Del-Ben, C. M., Vilela, J. A. A., Crippa, J. A. S., Hallak, J. E. C., Labate, C. M., \& Zuardi, A. W. (2001). Confiabilidade da "Entrevista Clínica Estruturada para DSM-IV: Versão Clínica" traduzida para o português. Revista Brasileira de Psiquiatria, 3(23), 156-159. http:// dx.doi.org/10.1590/S1516-44462001000300008

Dorsch, T. E., Smith, A. L., \& McDonough, M. H. (2015). Early socialization of parents through organized youth sport. Sport, Exercise, and Performance Psychology, 4(1), 3-18. http://dx.doi.org/10.1037/spy0000021

Ferriolli, S. H. T., Marturano, E. M., \& Puntel, L. P. (2007). Contexto familiar e problemas de saúde mental infantil no Programa Saúde da Família. Revista de Saúde Pública, 41(2), 251-259. http://dx.doi.org/10.1590/ S0034-89102006005000017

Fleitlich, B. W., Cortázar, P. G., \& Goodman, R. (2000). Questionário de capacidades e dificuldades (SDQ). Infanto: Revista de Neuropsiquiatria da Infância e da Adolescência, 1(8), 44-50.

Fosco, G. M., Stormshak, E. A., Dishion, T. J., \& Winter, C. E. (2012). Family relationships and parental monitoring during middle school as predictors of early adolescent problem behavior. Journal of Clinical Child and Adolescent Psychology, 41(2), 202-213. http://dx.doi. org/10.1080/15374416.2012.651989

Gomes, H. M. D. S., \& Pereira, M. G. (2014). Funcionamento familiar e delinquência juvenil: a mediação do autocontrolo. Análise Psicológica, 32(4), 439-451. http://dx.doi.org/1014417/ap.32.3.958

Goodman, R. (1997). The strengths and difficulties questionnaire: A research note. Journal of Child Psychology and Psychiatry, 38(5), 581-586. http:// dx.doi.org/10.1111/j.1469-7610.1997.tb01545.x

Goodman, S. H., Rouse, M. H., Connel, A. M., Broth, M. R., Hall, C. M., \& Heyward, D. (2011). Maternal depression and child psychopathology: A meta-analytic review. Clinical Child and Family Psychology Review, 14(1), 1-27. http://dx.doi.org/10.1007/s10567-010-00 80-1

Jacobs, R. H., Talati, A., Wickramaratne, P., \& Warner, V. (2015). The influence of paternal and maternal major depressive disorder on offspring psychiatric disorders. Journal of Child and Family Studies, 24(8), 2345-2351. http://dx.doi.org/10.1007/s10826-014-0037-y

Linhares, M. B. M. (2016). Estresse precoce no desenvolvimento: impactos na saúde e mecanismos de proteção. Estudos de Psicologia (Campinas) 33(4), 587-599. http://dx.doi.org/10.1590/1982-0275 2016000400003
Maroco, J. (2014). Análise estatística com o SPSS (6a ed.). Pêro Pinheiro: Report Number.

Marturano, E. M. (1999). Recursos no ambiente familiar e dificuldades de aprendizagem na escola. Psicologia: Teoria e Pesquisa, 15(2), 135-142. https://dx.doi. org/10.1590/S0102-37721999000200006

Marturano, E. M. (2006). O inventário de recursos do ambiente familiar. Psicologia: Reflexão e Crítica, 19(3), 498-506. http://dx.doi.org/10.1590/S010279722006000300019

Marturano, E. M., \& Elias, L. C. S. (2016). Família, dificuldades no aprendizado e problemas de comportamento em escolares. Educar em Revista, (59), 123-139. http://dx.doi.org/10.1590/0104-4060.44617

Mikkonen, J., Moustgaard, H., Remes, H., \& Martikainen, P. (2016). Intergenerational transmission of depressive symptoms: The role of gender, socioeconomic circumstances, and the accumulation of parental symptoms. Journal of Affective Disorders, 204, 74-82. http://dx.doi.org/10.1016/j.jad.2016.06.036

Pizeta, F. A. (2014). Depressão materna, estressores e resiliência: preditores do comportamento de escolares (Tese de doutorado). Recuperado em fevereiro 20, 2017, de http://www.teses.usp.br/teses/ disponiveis/17/17148/tde-10112014-213910

Pizeta, F. A., Silva, T. B. F., Cartafina, M. I. B., \& Loureiro, S. R. (2013). Depressão materna e riscos para o comportamento e a saúde mental das crianças: uma revisão. Estudos de Psicologia (Natal), 18(3), 429-437. http://dx.doi.org/10.1590/S1413-294X20 13000300003

Psychogiou, L., \& Parry, E. (2014). Why do depressed individuals have difficulties in their parenting role? Psychological Medicine, 44(7), 1345-1347. http://dx. doi.org/10.1017/S0033291713001931

Santos, L. C. (1999). Crianças com dificuldades de aprendizagem: estudo de seguimento (Dissertação de mestrado não-publicada). Universidade de São Paulo, Ribeirão Preto.

Shaw, D. S., Sitnick, S. L., Reuben, J., Dishion, T. J., \& Wilson, M. N. (2016). Transactional effects among maternal depression, neighborhood deprivation, and child conduct problems from early childhood through adolescence: A tale of two low-income samples. Development and Psychopathology, 28(3), 819-836. http://dx.doi.org/10.1017/S095457941600033X

Talati, A., Wickramaratne, P. J., Pilowsky, D. J., Alpert, J. E., Cerda, G., Garber, J., ... Weissman, M. M. (2007). Remission of maternal depression and child symptoms among single mothers: A STAR *D-Child report. Social Psychiatry and Psychiatric Epidemiology, 42(12), 962-971. http://dx.doi.org/10.1007/s00127-007-0262-4

Walsh, F. (2006). Strengthening Family Resilience (2nd ed). New York: Guilford Press. 
Walsh, F. (2016). Resiliência familiar. In F. Walsh (Org.), Processo normativos da família: diversidade e complexidade (4a ed). Porto Alegre: Artmed.

Woerner, W., Fleitlich-Bilyk, B., Martinussen, R., Fletcher, J., Cucchiaro, G., Dalgalarrondo, P., ... Tannock, R. (2004). The strengths and difficulties questionnaire overseas: Evaluations e applications of the SDQ beyond Europe. European Child and Adolescent Psychiatry, 13(Suppl 2), ii47-ii54. http://dx.doi.org/10.1007/ s00787-004-2008-0
World Health Organization. (2017). Depression and other common mental disorders: Global health estimates. Retrieved July 9, 2018, from http:// apps.who.int/iris/bitstream/handle/10665/254610/ WHO-MSD-MER-2017.2-eng.pdf; jsessionid=941E8 D6BCD7068FF960F8ACF5312F39? sequence =1

Received: February 23, 2017

Final version: June 14, 2017

Approved: August 7, 2017 